\title{
Estimates of habitat use by rabbits (Sylvilagus spp.) from fecal pellet counts varies by plot design in southern California
}

\author{
Sean P. Dunagan ${ }^{1}{ }^{*}$ and Tim J. Karels ${ }^{1}$ \\ ${ }^{1}$ Department of Biology, California State University, Northridge, 18111 Nordhoff Street, Northridge, CA 91330
}

\begin{abstract}
Studies of rabbits and hares often use fecal pellet counts to estimate population density, create indices of abundance, and monitor habitat use, because fecal pellet counts are more easily deployed and less labor intensive than visual surveys and live trapping. In some habitats, plot size and shape can affect the measured pellet density and the resulting estimates of habitat use by rabbits. We compared rabbit (Sylvilagus spp.) fecal pellet density estimates derived from $0.155-\mathrm{m}^{2}$ rectangular, $0.155-\mathrm{m}^{2}$ circular, $1-\mathrm{m}^{2}$ square, and $1-\mathrm{m}^{2}$ circular plots in southern California chaparral and coastal sage scrub communities to evaluate habitat use by rabbits. Pellet plots were not an effective sampling design in our chaparral site where rabbit pellet density was low. Our coastal sage scrub site had an abundance of fecal pellets, and pellet density estimates varied by plot design. The $0.155-\mathrm{m}^{2}$ plots were more easily deployed and counted, however they produced higher estimates of fecal pellet density, exhibited greater variance, and were unable to detect habitat differences in fecal pellet density. The $1-\mathrm{m}^{2}$ plots required more effort but produced lower pellet density estimates, exhibited less variation, and were both able to detect habitat differences in fecal pellet density. We recommend that researchers conducting rabbit fecal pellet counts in Californian Mediterranean scrub habitats use 1- $\mathrm{m}^{2}$ circular plots for their ease of deployment, counting, and clearing and for their greater detection and precision in estimates of pellet densities.
\end{abstract}

RESUMEN.-Los estudios sobre conejos y liebres, frecuentemente usan el conteo de pellet fecales para estimar su densidad poblaciónal, crear índices de abundancia y monitorear el uso de hábitat. Debido a que, este método es más fácil y requiere de una labor menos intensiva que los estudios visuales y el trampeo. El tamaño y la forma de las áreas muestreadas pueden influir en la medida de la densidad de los pellet fecales, ya que la variación en la superficie del terreno y la extensión de sus límites (relación perímetro-área) pueden dar generar diferentes estimados de la densidad. Para evaluar el uso de hábitat de los conejos, comparamos los estimados de la densidad de pellet fecales de los conejos Sylvilagus spp., provenientes de áreas de muestreo rectangulares de $0.155 \mathrm{~m}^{2}$, circulares de $0.155 \mathrm{~m}^{2}$, cuadradas de $1 \mathrm{~m}^{2}$ y circulares de $1 \mathrm{~m}^{2}$ en comunidades de chaparrales y matorrales costeros de salvia al sur de California. Las áreas de muestreo de pellets en la zona de los chaparrales no fueron efectivas, debido a que, la cantidad de pellet fecales fue baja. Las zonas de matorrales de salvia costera presentaron mayor cantidad de pellet fecales, las estimaciones de densidad variaron según el diseño (forma y tamaño) del área de muestreo. Las áreas de muestreo de $0.155 \mathrm{~m}^{2}$ fueron más fáciles de utilizar y contar. Sin embargo, estas produjeron estimaciones más altas de la densidad de pellet fecales, mayor variación y fueron ineficaces para detectar diferencias de hábitat en cuanto a la densidad de pellet fecales. Los sitios de muestreo de $1 \mathrm{~m}^{2}$ requirieron mayor esfuerzo, pero produjeron menores estimados de la cantidad de pellet fecales y menor variación, ambas fueron eficaces para detectar diferencias de hábitat en la densidad de pellet fecales. Recomendamos que los investigadores que realizan conteos de pellet fecales de conejo en los hábitats de matorrales del mediterráneo californiano, utilicen áreas de muestreo circulares de $1 \mathrm{~m}^{2}$, dada su facilidad de uso, conteo y limpieza, así como mayor capacidad de detección y precisión en las estimaciones de la densidad de pellet fecales.

Plot design is of interest to investigators because variation in plot size, shape, spatial arrangement, and replication can affect plot estimates and their variance (e.g., Cressie 1991, Thompson 1992, Thompson et al. 1998, Gregoire 1998, Krebs 1999). For animal populations, counting fecal pellets is an appealing method because it is nonintrusive, cost effec- tive, and time efficient (e.g., Bailey and Putman 1981, Karels et al. 2004, Ferretti et al. 2016). Strong relationships between fecal pellet density estimates and numbers of individuals has been shown for rabbits and hares (Krebs et al. 1987, 2001, Murray et al. 2002, Homyack et al. 2006, Berg and Gese 2010), allowing for the derivation of indices of

*Corresponding author: seandunagan@sbcglobal.net 
abundance that have been used in a range of ecological studies documenting habitat use (Litvaitis et al. 1985, Palomares 2001, Pierce et al. 2011), predator-prey dynamics (Bednarz and Ligon 1988, Gerstell and Bednarz 1999, McCann and Moen 2011), and conservation (Forys and Humphrey 1997).

The precision and accuracy of fecal pellet counts in monitoring populations is partially determined by plot area and shape. In a highdensity snowshoe hare (Lepus americanus) population in the Kluane boreal forest region, Krebs et al. $(1987,2001)$ used $0.155-\mathrm{m}^{2}(5.08$ $\times 305-\mathrm{cm})$ rectangular pellet plots because they produced the lowest variation compared to other plot designs and were easily sampled by 1 or 2 persons. However, Murray et al. (2002) tested plot size and shape for lowdensity hare populations in Idaho and reported that $1-\mathrm{m}^{2}$ circular plots produced lower variance and lower likelihood of empty plots compared with $0.155-\mathrm{m}^{2}$ rectangular and circular plots. Furthermore, McKelvey et al. (2002) reported that $0.155-\mathrm{m}^{2}$ rectangular plots produced pellet density estimates 2.3 times higher in Montana and 1.8 times higher in Idaho than larger $0.56-\mathrm{cm}$-radius $\left(0.985-\mathrm{m}^{2}\right.$ area) circular plots and that larger circular plots minimized inclusion bias of counting pellets that occur along plot boundaries.

Other leporid studies using fecal pellet counts have also considered a range of plot sizes and shapes. In the Mediterranean climate of southwestern Spain, Palomares (2001) used 0.7 -m-diameter $\left(0.385-\mathrm{m}^{2}\right)$ plots which were able to distinguish differences in pellet numbers among habitats for European rabbits (Oryctolagus cuniculus). Pierce et al. (2011) counted fecal pellets in $0.25-\mathrm{m}^{2}$ square quadrats to assess habitat use by pygmy rabbits (Brachylagus idahoensis), cottontail rabbits (Sylvilagus spp.), and black-tailed jackrabbits (Lepus californicus) in a sagebrush community in Utah. Forys and Humphrey (1997) used concentric $0.5-\mathrm{m}^{2}$ and $1-\mathrm{m}^{2}$ circular plots in Florida to estimate densities of the endangered Lower Keys marsh rabbit (Sylvilagus palustris hefneri). Bednarz and Ligon (1988), Gerstell and Bednarz (1999), and McCann and Moen (2011) all used plots with a $1-\mathrm{m}^{2}$ area to quantify lagomorph species as prey items for local predators. There are numerous plot designs used to estimate leporid fecal pellet density because pellet density estimates can vary by species, habitat, and population density.

The purpose of our investigation was to determine (1) whether plot size (area) and shape (perimeter-to-area ratio or plot edge) influence pellet density estimates and the associated variance and (2) whether estimates of habitat use by rabbits vary by plot design. We tested 4 pellet plot designs-0.155-m² rectangular, $0.155-\mathrm{m}^{2}$ circular, $1-\mathrm{m}^{2}$ square, and $1-\mathrm{m}^{2}$ circular pellet plots-in a coastal sage scrub and a chaparral community in southern California. We chose to test these plot designs because they have been evaluated in other leporid studies, and fecal pellet counts derived from these designs have produced strong regressions with the enumeration of individuals (Krebs et al. 1987, 2001, McKelvey et al. 2002, Murray et al. 2002). Two species of rabbit occur in this area, the desert cottontail rabbit (Sylvilagus audubonii) and the brush rabbit (Sylvilagus bachmani). We did not discriminate between the pellets of the 2 species. The results of this study then determined the plot design to be used in a subsequent study investigating habitat selection of bobcats (Lynx rufus) in relationship to rabbit abundance. Rabbits are an important food resource for bobcats in this area (Riley et al. 2010); thus, we required a suitable index of abundance that could detect differences in habitat use because numerical estimation of rabbit densities in various habitat types at a large scale was not feasible.

\section{STUdy AREA}

We estimated rabbit fecal pellet density in 2 southern Californian coastal communities from May to August in 2012. The first study area was a coastal sage scrub community located in Cheseboro Canyon in Agoura Hills, California $\left(34.1517^{\circ} \mathrm{N}, 118.7342^{\circ} \mathrm{W}\right)$. Vegetation composition is dominated by purple sage (Salvia leucophylla) and includes black sage (Salvia mellifera), California sage-brush (Artemisia californica), California buckwheat (Eriogonum fasciculatum), ashy leaf buckwheat (Eriogonum cinereum), coast live oak (Quercus agrifolia), laurel sumac (Malosma laurina), and coyote bush (Baccharis pilularis). This study site also includes open grassy areas dominated by annuals such as brome grasses (Bromus spp.), wild oats (Avena spp.), black 
TABLE 1. Maximum, mean, and percent coefficient of variation $(\mathrm{CV})$ of cottontail rabbit fecal pellets (pellets per $\mathrm{m}^{2}$ ) of varying plot size and shape at Cheseboro Canyon, California. $\mathrm{R}=$ rectangle, $\mathrm{C}=$ Circle, $\mathrm{Sq}=$ square.

\begin{tabular}{lcccr}
\hline & \multicolumn{4}{c}{ Plot types } \\
\cline { 2 - 5 } & $0.155 \mathrm{~m}^{2}$ & $0.155 \mathrm{~m}^{2}$ & $1 \mathrm{~m}^{2}$ & $1 \mathrm{~m}^{2}$ \\
& $\mathrm{C}$ & $\mathrm{R}$ & $\mathrm{Sq}$ & $\mathrm{C}$ \\
\hline Maximum & 412.9 & 929.0 & 198.0 & 182.0 \\
Mean & 79.2 & 132.6 & 38.7 & 44.2 \\
Percent CV & 157.0 & 184.9 & 133.3 & 120.5 \\
\hline
\end{tabular}

mustard (Brassica nigra), shortpod mustard (Hirschfeldia incana), and Italian thistle (Carduus pycnocephalus). The second study area was a chaparral community located at Stunt Ranch Reserve in the Santa Monica Mountains $\left(34.0941^{\circ} \mathrm{N}, 118.6565^{\circ} \mathrm{W}\right)$. The vegetation community there is dominated by chamise (Adenostoma fasciculatum), manzanita (Arctostaphylos spp.), scrub oaks (Quercus spp.), and sumacs (Rhus spp.). This area also has a cleared open area composed of similar brome grasses and invasive annuals.

\section{METHods}

We deployed fecal pellet plots in sets of 4 different designs $-0.155-\mathrm{m}^{2}$ rectangular, $0.155-\mathrm{m}^{2}$ circular, $1-\mathrm{m}^{2}$ square, and $1-\mathrm{m}^{2}$ circular pellet plots-in 3 different habitat categories at each site. A set of plots was first established at the edge habitats (edge plots), a second set of plots was placed $50 \mathrm{~m}$ perpendicular to the edge into neighboring coastal sage scrub/ chaparral habitat (scrub plots), and a third set of plots was placed $50 \mathrm{~m}$ perpendicular to the edge into open grassy habitat (grass plots). This array design (4 plot types in 3 habitats) was then replicated 6 times at each site along a $600-\mathrm{m}$ stretch of edge habitat with $100 \mathrm{~m}$ between arrays for a total of 144 plots. Although we attempted to follow this design as closely as possible, the thin linear shape of the open grassy area at Stunt Ranch prevented us from placing some of the grass plots at $50 \mathrm{~m}$ from chaparral edges. In those cases, the grass pellet plots were placed the maximum distance possible from dense chaparral (range 20-30 m).

All 4 plot types were deployed at each location with each plot design type separated by $1 \mathrm{~m}$ from each other in a linear and random order. Plot locations were marked with $0.5-\mathrm{m}$ long steel rebar stakes and were cleared of all fecal pellets. Plots were counted and then cleared after a 3-month period to allow rabbits enough time to deposit pellets. All fecal pellets that occurred on the plot edge were included in our pellet density estimate. This positive bias is common in ecological sampling because researchers are more likely to include data than exclude it (Krebs 1999), which in our study would most likely influence the variance of our $0.155-\mathrm{m}^{2}$ rectangular and $1-\mathrm{m}^{2}$ square plots. Rabbit fecal pellet density was calculated as the number of pellets per day per square meter $\left(\mathrm{m}^{2}\right)$. We tested for the differences in the fecal pellet density among habitats using a single factor ANOVA with a post hoc analysis using Tukey's multiple comparison procedure for each plot design. Fecal pellet counts were transformed for analysis as $\log _{\mathrm{e}}(x+1)$.

\section{RESUlTS}

We counted a total of 2084 fecal pellets in Cheseboro Canyon and 143 pellets at Stunt Ranch. Rabbit fecal pellet density was too low at the Stunt Ranch chaparral site to produce any usable data, with only 13 out of 72 plots having any fecal pellets deposited. Rabbit fecal pellet density was much higher in Cheseboro Canyon, with 64 of the 72 plots having fecal pellets deposited. In Cheseboro Canyon 13 of eighteen $0.155-\mathrm{m}^{2}$ circular plots had pellets present, 16 of eighteen $0.155-\mathrm{m}^{2}$ rectangular plots had pellets, 17 of eighteen $1-\mathrm{m}^{2}$ square plots had pellets, and all eighteen $1-\mathrm{m}^{2}$ circular plots had pellets. Both $0.155-\mathrm{m}^{2}$ pellet plot designs produced higher pellet density estimates and had more variance than both $1-\mathrm{m}^{2}$ plot designs. The long and thin $0.155-\mathrm{m}^{2}$ rectangular plots yielded the largest pellet density estimate and had the greatest coefficient of variance (Table 1).

We observed differences in the ability of plot designs to detect differences in pellet density among habitats. Small $0.155-\mathrm{m}^{2}$ circular plots were unable to detect any differences in pellet density among habitat types $\left(F_{2,15}=\right.$ $3.2, P=0.07)$. However, rectangular $0.155-\mathrm{m}^{2}$ plots did detect significance differences in pellet density among habitats $\left(F_{2,15}=6.7, P=\right.$ $0.008)$, with a greater density of pellets in edge habitats compared to scrub habitats (Tukey's pairwise comparison: $P=0.007$ ) (Fig. 1). Both $1-\mathrm{m}^{2}$ square $\left(F_{2,15}=12.2, P=0.001\right)$ and 

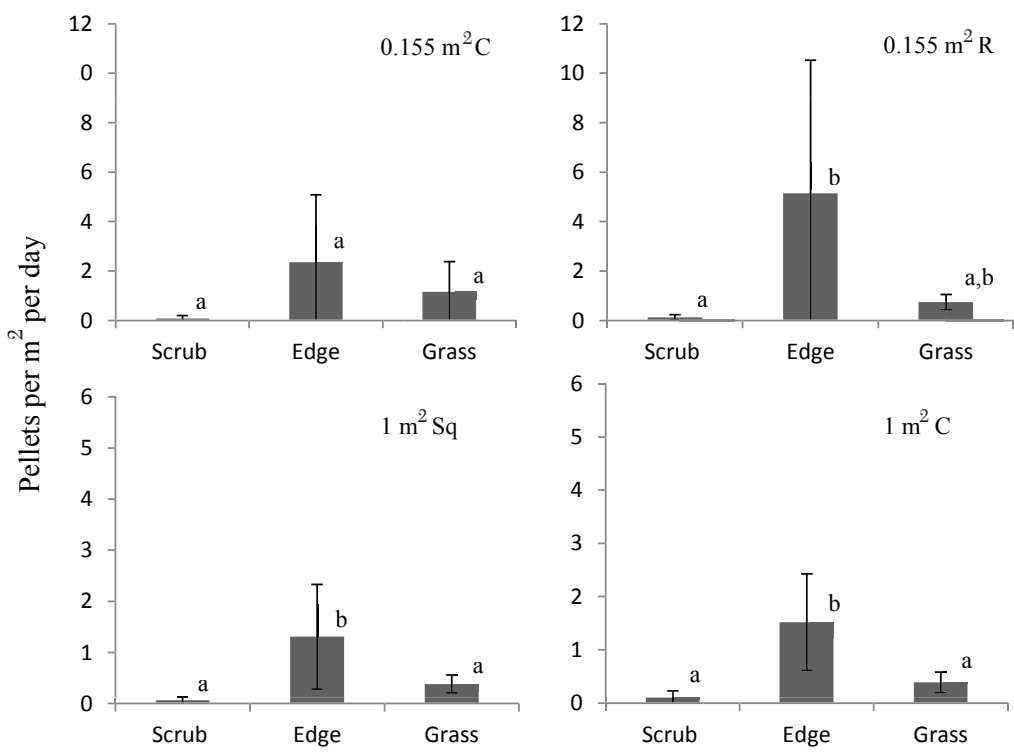

Fig. 1. Mean cottontail rabbit fecal pellet density for $0.155-\mathrm{m}^{2}$ circular, $0.155-\mathrm{m}^{2}$ rectangular, $1-\mathrm{m}^{2}$ square, and $1-\mathrm{m}^{2}$ circular plots. Error bars represent standard deviation. Letters denote significant $(P<0.05)$ differences in fecal pellet counts by habitat classification from Tukey's pairwise comparisons.

circular $\left(F_{2,15}=16.6, P<0.001\right)$ plot designs yielded significant differences among habitats. Pairwise comparisons for $1-\mathrm{m}^{2}$ square plots showed that pellet densities in edge habitat were greater than in scrub habitat $(P=0.001)$ or in grass habitat $(P=0.019)$ (Fig. 1). Pairwise comparison for $1-\mathrm{m}^{2}$ circular plots showed the same relationship, with pellet densities in edge habitat being greater than in scrub habitat $(P<0.001)$ and grass habitat $(P=$ 0.003) (Fig. 1).

\section{Discussion}

Our study indicates that plot size and shape can affect rabbit fecal pellet density estimates, their variance, and the ability to detect differences in pellet density between habitats in southern California coastal sage scrub communities. Area had the greatest effect on fecal pellet estimates with $0.155-\mathrm{m}^{2}$ rectangular and circular plots producing higher pellet density estimates and having greater variance than the larger $1-\mathrm{m}^{2}$ circular and square plots. Plot shape had a greater effect on $0.155-\mathrm{m}^{2}$ plots than on $1-\mathrm{m}^{2}$ plots likely due to the greater difference in plot edge and the subsequent positive bias of including more fecal pellets that occurred along the plot edge of the long and thin $0.155-\mathrm{m}^{2}$ rectangular plots.
Furthermore, the $0.155-\mathrm{m}^{2}$ circular plots were unable to detect any differences in pellet density between habitats, whereas the $0.155-\mathrm{m}^{2}$ rectangular plots detected differences in pellet density between edge and scrub habitats but not edge and grass habitats (Fig. 1). Circular $0.155-\mathrm{m}^{2}$ plots had a greater likelihood of having no pellets, likely because plots did not intersect clumps of rabbit fecal pellets. Circular and square $1-\mathrm{m}^{2}$ plots detected the same pattern of habitat use and had only slight differences between them whereas the $1-\mathrm{m}^{2}$ square plots had lower pellet density estimates with higher variance than $1-\mathrm{m}^{2}$ circular plots.

An important inference from our study is that estimates of habitat use by rabbits in our coastal sage scrub site changed with plot design. Our $1-\mathrm{m}^{2}$ plots were able to detect differences in habitat use by rabbits but whether $1-\mathrm{m}^{2}$ plots are an appropriate design for sampling rabbit (Sylvilagus spp.) fecal pellets in other habitats or during different seasons is unknown. There does not appear to be any standard plot design using fecal pellet counts that is optimal for estimating habitat use by rabbits. Many different plot designs with varying size, shape, and layout have been used to successfully quantify relative habitat use by leporids. For example, Pierce et al. (2011) found that $0.25-\mathrm{m}^{2}$ square quadrats 
placed at 3, 6, and $9 \mathrm{~m}$ within $10-\mathrm{m}$ segments of 30-m-long transects detected increased use of habitat edges by cottontail rabbits and jackrabbits in Utah. Litvaitis et al. (1985) used 1 -m-radius plots, roughly 3 times larger than our $1-\mathrm{m}^{2}$ plots, placed at $50-\mathrm{m}$ intervals along $700-\mathrm{m}$ transects to detect habitat use by snowshoe hares in Maine. Palomares (2001) was able to detect differences in habitat use by European rabbits in southwestern Spain with fifteen $0.7-\mathrm{m}$-diameter $\left(0.385-\mathrm{m}^{2}\right)$ plots established in each habitat category placed 80-100 m apart.

Our results (Table 1) are consistent with Murray et al. (2002), who tested similar plot designs in a low-density snowshoe hare population and found that $0.155-\mathrm{m}^{2}$ rectangular plots showed the greatest variation in fecal pellets and $1-\mathrm{m}^{2}$ circular plots showed the least variation. Also, $1-\mathrm{m}^{2}$ plots were less likely to be empty compared to $0.155-\mathrm{m}^{2}$ plots. Our results are also consistent with McKelvey et al. (2002) who showed that $0.155-\mathrm{m}^{2}$ rectangular plots produced greater pellet density estimates and had greater variance than $1-\mathrm{m}^{2}$ circular plots.

Plot size and shape are important considerations but spatial arrangement and replication may also affect pellet density estimates from plot sampling (Krebs 1999). There are several possible sources of variation in fecal pellet density estimates that we did not measure. First, rabbits may defecate more on feeding grounds than in areas where they rest (Gibb 1993, Palomares 2001); thus, fecal pellet density estimates may be biased toward areas that are used when rabbits are active. However, Forys and Humphrey (1997) report a strong correlation between radio-collared marsh rabbits and pellet counts, so even if rabbits produce more pellets when foraging, that effect is not sufficient to significantly alter the relationship between pellet abundance and time spent in an area. Second, rabbits and other passing animals may kick fecal pellets into or out of pellet plots (Krebs et al. 2001); however, we have no reason to suspect this as a cause of bias in our estimates since we assumed that this type of disturbance is random. Third, pellet degradation is influenced by environmental conditions and therefore rates of pellet retention can vary by habitat (Prugh and Krebs 2004) and by humidity and precipitation (Flinders and Crawford 1977).
We assumed any biases introduced by environmental differences to be minimal since our study area is very dry, which promotes pellet longevity (Murray et al. 2005, Fernandez-deSimon et al. 2011).

In this study, $1-\mathrm{m}^{2}$ pellet plots performed well in our coastal sage scrub site where rabbit fecal pellets were abundant; however, pellet plots were not an effective sampling design in our chaparral site, where rabbit fecal pellet abundance was low. It was our experience that although $0.155-\mathrm{m}^{2}$ circular plots and $0.155-\mathrm{m}^{2}$ rectangular plots required the least amount of effort to deploy and count, these plot designs produced greater density estimates and greater variance and were not able to detect differences in habitat use by rabbits (Table 1, Fig. 1). Both $1-\mathrm{m}^{2}$ plot shapes were similar in their pellet density estimates, variance, and ability to detect differences in fecal pellets between habitats; however, it was our experience that $1-\mathrm{m}^{2}$ circular plots with their minimized plot edge were easier to deploy, count, and clear in the dense coastal sage scrub habitat than $1-\mathrm{m}^{2}$ square plots. To our knowledge this is the first study to quantify how fecal pellet plot design affects pellet density estimates in this region of North America. We contend that fecal pellet plots are an effective way to obtain a relative index of abundance and document habitat use by rabbits if enumeration of individuals by high-cost and high-effort techniques such as live trapping or visual line-transect sampling are not feasible. We recommend that researchers who conduct fecal pellets counts in Mediterranean scrub habitats in southern California use a larger-area plot design to reduce the variance in their pellet density estimates.

\section{ACKNOWLEDGMENTS}

Thanks to Alex Johnson for providing assistance in the field. Funding was provided by the Newhall Land and Farming Southern California Ecology grant and California State University, Northridge. Land use permission was provided by Santa Monica Mountains National Recreation Area and UCLA Stunt Ranch - UC Natural Reserve System

\section{Literature Cited}

Bailey, R.E., AND R.J. PUtMan. 1981. Estimation of fallow deer (Dama dama) populations from faecal accumulation. Journal of Applied Ecology 18:697-702. 
BednaRZ, J.C., AND J.D. LigOn. 1988. A study of the ecological basis of cooperative breeding in Harris' Hawk. Ecology 69:1176-1187.

BERG, N.D., AND E.M. GESE. 2010. Relationship between fecal pellet counts and snowshoe hare density in western Wyoming. Journal of Wildlife Management 74:1745-1751.

Cressie, N.A.C. 1991. Statistics for spatial data. Wiley, New York, NY.

Fernandez-De-Simon, J., F. Diaz-Ruiz, R. Villafuerte, M. Delibes-Mateos, and P. Ferreras. 2011. Assessing predictors of pellet persistence in European rabbits Oryctolagus cuniculus: towards reliable population estimates from pellet counts. Wildlife Biology 17:317-325.

Ferretti, F., L. Fattorini, A. Sforzi, and C. Pisani. 2016. The use of faeces counts to estimate relative densities of wild boar in a Mediterranean area. Population Ecology 58:329-334.

Flinders, J.T., AND J.A. Crawford. 1977. Composition and degradation of jackrabbit and cottontail fecal pellets, Texas High Plains. Journal of Range Management 30:217-220.

Forys, E.A., AND S.R. Humphrey. 1997. Comparison of 2 methods to estimate density of an endangered lagomorph. Journal of Wildlife Management 61:86-92.

Gerstell, A.T., and J.C. Bednarz. 1999. Competition and patterns of resource use by two sympatric raptors. Condor 101:557-565.

GiBB, J.A. 1993. Sociality, time and space in a sparse population of rabbits (Oryctolagus cuniculus). Journal of Zoology, London 229:581-607.

Gregoire, T.G. 1998. Design-based and model-based inference in survey sampling: appreciating the difference. Canadian Journal of Forest Research 28: 1429-1447.

Homyack, J.A., D.J. Harrison, J.A. Litvaitis, and W.B. KroHN. 2006. Quantifying densities of snowshoe hares in Maine using pellet plots. Wildlife Society Bulletin 34:74-80.

Karels, T.J., L. Koppel, And D.S. Hik. 2004. Fecal pellet counts as a technique for monitoring an alpinedwelling social rodent, the hoary marmot (Marmota caligata). Artic, Antarctic, and Alpine Research 36: 490-494.

Krebs, C.J. 1999. Ecological methodology. 2nd edition. Addison Wesley Longman Inc., Menlo Park, CA.

Krebs, C.J., R. Boonstra, V. Nams, M. O’Donoghue, K.E. Hodges, And S. Boutin. 2001. Estimating snowshoe hare population density from pellet plots: a further evaluation. Canadian Journal of Zoology $79: 1-4$.
Krebs, C.J., B.S. Gilbert, S. Boutin, and R. Boonstra. 1987. Estimation of snowshoe hare population density from turd transects. Canadian Journal of Zoology 65:565-567.

Litvaitis, J.A., J.A. Sherburne, and J.A. Bissonette. 1985. Influence of understory characteristics on snowshoe hare habitat use and density. Journal of Wildlife Management 49:866-873.

McCann, N.P., And R.A. Moen. 2011. Mapping potential core areas for lynx (Lynx canadensis) using pellet counts from snowshoe hares (Lepus americanus) and satellite imagery. Canadian Journal of Zoology 89:509-516.

McKelvey, K.S., G.W. McDaniel, L.S. Mills, and P.C. Griffin. 2002. Effects of plot size and shape on pellet density estimates for snowshoe hares. Wildlife Society Bulletin 30:751-755.

Murray, D.L., E. Ellsworth, and A. Zack. 2005. Assessment of potential bias with snowshoe hare fecal pellet-plot counts. Journal of Wildlife Management 69:385-395.

Murray, D.L., J.D. Roth, E. Ellsworth, A.J. Wirsing, AND T.D. Steury. 2002. Estimating low-density snowshoe hare populations using fecal pellet counts. Canadian Journal of Zoology 80:771-781.

Palomares, F. 2001. Comparison of 3 methods to estimate rabbit abundance in a Mediterranean environment. Wildlife Society Bulletin 29:578-585.

Pierce, J.E., R.T. Larsen, J.T. Flinders, and J.C. WhitING. 2011. Fragmentation of sagebrush communities: does an increase in habitat edge impact pygmy rabbits? Animal Conservation 14:314-321.

Prugh, L.R., AND C.J. KREBs. 2004. Snowshoe hare pelletdecay rates and aging in different habitats. Wildlife Society Bulletin 32:386-393.

Riley, S.P.D., E.E. Boyston, K.R. Crooks, and L.M. LyREN. 2010. Bobcats (Lynx rufus) Pages 121-138 in S.D. Gehrt, S.P.D. Riley, and B.L. Cypher, editors, Urban carnivores: ecology, conflict, and conservation. Johns Hopkins University Press, Baltimore, MD.

Thompson, S.K. 1992. Sampling. Wiley, New York, NY.

Thompson, W., G. White, And C. Gowan. 1998. Monitoring vertebrate populations. Academic Press. 365 pp.

Received 31 July 2017 Revised 31 October 2017

Accepted 13 November 2017

Published online 7 March 2018 